\title{
Named and shamed
}

\section{ネット上での名指し告発に潜む恐怖}

Nature Vol.441(392-393)/25 May 2006

中国で過熱化する科学的不正への批判に対し、文化大革命時に行われたいわれのない迫害の歴史を彷彿させるという 懸念を抱く人たちがいる。David Cyranoski が報告する。

中国の科学研究は、まるで両內の剣の両辺 ともで斬り落とされてしまいそうだ。かた やはびこる科学的不正、かたや根拠のない 疑惑で追い詰められる恐ろしさだ。

公的機関が不正をきちんと調査しない という人々の不信感を背景に、中国では 科学者の経歴や論文が正当なものである かどうかに疑問を問いかけるウェブサイ トが注目を集めている。しかし一方では、 調査も行わずに根拠のない疑惑を投げか けるそうした手法が生み出す弊害につい て懸念する声も多く聞かれてきている。 このほど米国に拠点を置く 100 人以上の 中国人科学者から中国政府に送られた公 開書簡は、指摘された科学的不正の疑惑 に対し、公正な調査を保障する公的機関 を設置するよう要求するものであった。

論文の盗用、およびデータのねつ造や 改ざんを含む科学的不正が中国国内で深 刻な問題となっていることは、中国政府 も認めている。不正の規模がどれほどか は不明だが、最近の相次ぐ疑惑の浮上が、 この問題の広がりを浮きぼりにしている。

3 月、北京にある清華大学医学院の副 学院長 Hui Liu が、業績をよくみせかけ るために別人の H. Liu の論文を自分の論 文リストに加えていたという理由で解雇 処分となった (Nature 440, 728; 2006 参照)。伝えられるところによると、Liu は疑惑を否定しており、事務処理時の手 違いだったと主張している。また 4 月に は、成都の四川大学が中国のマスメディ アから批判を受けた。論文のねつ造を疑 われていた同大学の教授が潔白であると
結論づけたためだ。問題の論文について は 2000 年の発表以来、ほかの研究者か ら疑念の声が上がっていた。さらには 5 月半ばになると、2003 年に中国で最初に デジタル信号処理チップを発表し愛国心 をかきたてた 1 人である上海交通大学の JinChenについて、大学側が、研究はね つ造されたもので、海外企業のデザイン の盗用も行われていたと発表した。

これらの3つの疑惑すべてにおいて、 一般の人々の感情にさらに油を注ぐ中心 的な役割を果たしたウェブサイトがある。 人気の高い中国語のウェブサイト、New Threads(www.xys.org)だ。このサイ トは中国の科学的不正を暴くことで評判 になっている。

最初の 2 ケースでは、New Threads へ 疑惑が投稿されたことをきっかけに中国の マスメディアが記事として取り上げた。ま た、ウェブサイトの管理人でカリフォルニ ア州サンディエゴを拠点にする生化学者の Shi-min Fang は、Chen の件についても、 海外から入手したチップのラベルを張り替 えていたとされる会社の名前を最初に掲載 したのは自分だと主張している。

そうしたなか、適切な公的調査機関が 欠如している中国では今、いやおうなし に科学者を巻き込むウェブサイトのカが 大きな懸案事項となっている。

インディアナ大学（同州インディアナ ポリス）の免疫学者Xin-Yuan Fuは、四 川大学の一件で、中国科学技術大臣や中 国科学院学院長などの主要な政策当局に 対し、何らかの対応策を講じるよう求め
る公開書簡を書くことを決意したと話す。 この書簡の内容は、彼の仲間内で深い共 感をよんだ。在米の中国人生物学者たち の間で 5 日間回覧され、中国を拠点に置 く研究者 2 人を含む 120 名分の署名を集 めた。「とても驚いた」とFuはと話す。

この公開書簡で Fu はまず、不正はいか なる場合であっても公表されるべきであ るとしたうえで、根拠のない疑惑、特に 実験過程に故意の作為があったという証 拠をなんら示すことなく、科学的主張に 対して批判を展開することの問題性に言 及している。書簡は最後に、「適切な調査 が行われないままに……公の場において 匿名で個人を攻撃する」傾向を強く非難 する内容で締めくくられている。

Fuは、四川大学のケースがその典型的な 例だという。同大学の副学長 Yuquan Wei は 2000 年、ドナー由来の内皮細胞を腫 瘍の成長を予防するワクチンとして使用す る方法について詳しく述べた論文を Nature Medicine に掲載した。この論文でWei は、 マウス実験での成功を主張し、この方法 をヒトに適用できる可能性も示唆している (Nature Med. 6, 1160-1166; 2000)。

しかし 2001 年、Wei の助成金申請 を検討していたときにこの論文を初めて 目にした西安交通大学の免疫病理学者 LushengSi は、論文にはねつ造データが 含まれているのではないかと疑った。そ の後、さらに多額の助成金申請にWei が 同じ論文を使っていると聞いたSi は、今 年 3 月 26 日、New Threads 上でその論 文を告発した。 
この投稿をきっかけに中国メディアが 騷ぎ立て、大学側は学内調査に動いた。 そして四川大学は、Wei はいかなる不正 も㗢いておらず、Wei の研究について起 きている論争はどこにでもある学術的な 意見の相違であると結論づけた。その後 も中国メディアはWei と四川大学への批 判を続けたが、一方で多くの科学者は、Si の主張は無責任であり、科学的コンセプ 卜や実験過程に対するあやふやな解釈に 基づいたものだととらえている。

たとえば、Si はマウスの免疫システ ムは外来細胞のあらゆるタンパク質に反 応するはずだと強く主張するが、反対に Wei の論文は、免疫性を与えられたマウ スは選択的にごく少数の抗原に反応する としている。「このこと自体、免疫学の基 本的な法則に反する主張だ」とSi はいう。 だが、Fuの公開書簡への署名も行った ジョンズ・ホプキンス大学医学系大学院 (メリーランド州ボルティモア) の免疫学 者 Lieping Chen は、Si の意見に賛成し ていない。Chenによると、1つないし少 数の抗原タンパク質に対する選択的な免 疫反応は、よく知られた免疫優勢とよば れる現象の特徵の 1 つだという。

Si はまた、Wei が実験に使った約 4 万 匹とも推定されるマウスの数にも疑問を もっており、「これほど大量のマウスを 使ったとは信じがたい」と述べている。 Chenの支持を受けたWei はこの件に関 して、Siが計算を誤ったもので、実際に 使われたマウスの数は 5,000 匹に満たな いとしている。

しかしながらWei を擁護する人々も、 Wei の対応は疑惑を晴らすには不十分だ と認めている。たとえば、多くの研究者 はWei が生データを公表すれば問題は 解決すると考えているが、Siが要求する データの公開をWei はいまだに拒んでい る。ネイチャーの取材に対してWei は、 「調査が入った場合に生データを公開でき ないとはいっていない」と述べたものの、 データを今後公開する用意があるかどう かについては明確にしなかった。取材の 中でWei は、疑われている不正行為はな かったと全面的に否定した。
しかし、大学側の調査は透明性に欠け ており、多くの人々はいまだに真実が完 全に明らかになったとは考えていない。 「不正疑惑に関する四川大学の学内調査 は、まったく話にならない」と話すのは、 カリフォルニア大学バークレー校の神経 生物学者で、上海神経科学研究所の所長 を務めるMu-ming PoOだ。ネイチャー は、大学側の行った調査の詳しい内容や 調査委員会のメンバーに関する情報の提 供を大学に依頼したが、回答はWei に委 任された。本記事が掲載された 5 月 25 日号の Nature が印刷にまわされる時点で、 依然Wei からの回答は得られなかった。

Pooはこの一件をめぐり、中国のほと んどの大学には適切な学内調査を実施する 能力が欠けていることを確信したという。 $\ulcorner($ 学內調査の) 結果は、大学の評判を落と したくないなどの大学側の思惑に左右され がちだ」とPOOは話す。

5 月 8 日に送られたFuの公開書簡は、 科学技術省や中国科学院 (CAS)、中国国家 自然科学基金委員会 (NSFC) などの資金 配分を行う政府上層機関がこの問題にきち んと関与するよう要求している。

これらの機関はすでに、独自の調査機関 をもっている。CAS は 1997 年に倫理委員 会を設立し、2001 年にはガイドラインを 草案した。1998 年に設立された NSFC 委 員会は、設立 5 年で（同期間に助成金を受 け取った、推定 3 万件の研究プロジェクト のうち）445 件の不正疑惑を調査したとい う。悪質な不正が行われていた場合、委員 会により無期限で助成金申請を阻止される。

しかし、多くの科学者はこれらの委員 会は問題の解決に役立っておらず、委員 会に対するこうした不信がインターネッ 卜上で告発が飛び交う原因だと感じてい る。たとえば Si は、CAS や科学技術省宛 てに疑念を伝えようとしたものの、どち らの連絡先も見つけることができなかっ たため、New Threadsへ投稿すること にしたという。ネイチャーでもCASや NSFCの委員会に連絡を取ろうと試みた が、失敗に終わった。

$\mathrm{Fu}$ は、「（正しく）機能していない公的 機関の存在こそが、New Threads の重要
性を高めている」と話す、しかし人権擁護 者でもある Fuは、ウェブサイト上で自分 の身元も明かさずに投稿されるような無責 任な疑惑を取り上げるマスコミの行き過ぎ た取材合戦は、中国のポスター「大字報」 を思い起こさせるとの懸念を示している。

この壁に張り出された手書きのポスター は、1970 年代の文化大革命下の中国で、 政府の敵とみなされた者を迫害するために 使われた。「誰でも好き勝手に書くことが でき、それを読んだ者は書かれた内容が真 実であると思い込んだ」とChen はいう。 「もし、それと同じことが中国の学術界で 繰り返されるとすれば、痛ましいことだ」。 2001 年のサイト立ち上げ以来、倫理を 欠いた科学研究を批判し、研究倫理に対 する中国国内での関心を高めようと努力 してきたとして多方面からの評価を受け たFang は、ウェブサイトへの投稿を擁護 する。Fangは、送られてくる投稿文のう ち採用するのは 1 割ほどにすぎず、なか でもウェブサイト上に公開する不正疑惑は Fang に身元を明かした投稿者によって書 かれたものだけだという。さらに、彼自身 が予備調査を行ったり、外部の専門家に意 見を求めたりすることもあると話す。

その一方で、ネイチャーに寄せられた科 学者からの意見の中には、あまりにも強大 になった Fang のウェブサイトの影響力に 対する不安を述べたものがいくつかあっ た。ただしこれらの科学者は、Fangに敵 とみなされるのを恐れ、名前は伏せてほし いとのことだった。

中国政府には、科学的不正疑惑を適切 に調査できる、訓練を受けた専門家で構成 される新しい調査機関を設立してもらいた い、米国研究公正局のような機関が理想的 だろうと Fu は語る。Nature Medicine の編 集長 Juan-Carlos Lopez も、Si 対 Wei の 一件を解決するためにもそういった機関が 必要だという。「『ああ言えばこう言う』の 繰り返しはもうたくさんだ。監督官庁が腰 を上げる時ではないか」と Lopez は話す。

実際それが実現するか否か、先行きは 不透明だ。Fuや共同署名者たちのもとに は、いまだ中国政府からの回答は届いて いないという。 